\title{
CORRESPONDENCE
}

\section{Dismissal of Professor Scheer was justified}

SIR, - As a member of the federal state government of Bremen I would like to make the following remarks to correct the letter from Uwe Lahl and W. Thiemann of Bremen University (27 September, page 252).

The Senate of the Freie Hansestadt Bremen, the federal state government, has not pursued the dismissal of Professor Jens Scheer from the Bremen civil service because of his political and scientific activities involved with his criticism of the nuclear politics of the Federal Republic of Germany. The Freie Hansestadt Bremen, even the Senate itself, is in fact taking a decidedly critical position regarding the nuclear politics of the Federal Republic of Germany.

Nor has the Bremen government pursued the dismissal of Professor Scheer primarily because he belongs to a non-prohibited political party (the KPD; the Communist Party of Germany). The real reason which has tipped the scales towards disciplinary action against Professor Scheer is rather as follows.

Professor Scheer advocates in public and in Bremen University, while practicing his public duties and abusing his official position, the removal of our free democratic constitutiona state of the Federal Republic by violence, and the erection of the dictatorship of the proletariat in its place; this in reality would be the dictatorship of a small elite. In making this aim (of violence) the declared object of his public service activities he abuses the official position given to him.

By the way Professor Scheer has advocated the use of violence not merely verbally, he has already been sentenced for taking part in violence against persons dissenting from his political opinion.

Therefore one cannot reasonably talk about the Bremen State trying to bring scientists under political control by this disciplinary action. Professor Scheer can make use of his constitutional rights in every allowable way. But he cannot legally claim the violent destruction of this state, and at the same time accept payment by the state. All civil rights remain guaranteed to Professor Scheer as a citizen and a scientist of this republic.

The Bremen state government is anxious to learn from German history. The first German Republic of Weimar allowed civil servants to challenge the state which they were sworn to serve, and in the end even to bring about its ruin. The Federal Republic of Germany and especially the German Social Democrats to which I belong have learned their lesson from Weimar.

Finally, the statement "He was not allowed a complete defence" is spun out of thin air. He and his lawyer had every opportunity to plead their position, and they did use it. Yours faithfully,

FRANKE

Freie Hansestad

Bremen, FRG

\section{The Sirius Mystery}

SIR, - Readers of Nature may well be aware from the review of my book The Sirius Mystery in the issue of 17 June, 1976 (pages 617-8), that "the problem of the remarkable knowledge of the Dogon people of Mali" referred to by Michael Rowan-Robinson in his review of Carl Sagan's Broca's Brain (8 November, 1979, pages 176-7), was first brought to public attention by myself. Although in his review Rowan-Robinson does not mention me by name, and in his book
Sagan barely refers to my seminal position with regard to public knowledge of this material except in passing, anyone truly interested in this subject is perfectly aware that they are referring to myself when discussing this matter.

It would be inappropriate for me to discuss Sagan's own errors here. But I would like to reply to statements made by Rowan-Robinson, who says that "Sagan has performed a useful service in collecting together examples of public gullibility and demonstrating how a mixture of deliberate fraud and uncritical thinking has allowed millions to be bamboozled ...". He says this immediately after discussing my material.

I strongly object to the inference that I have been guilty of fraud in bamboozling a gullible public, and as for "uncritical thinking", the many serious and thoughtful reviews of my book in this very journal as well as others of distinction testify to the fact that although the implications of my work have aroused controversy, it is not widely thought, nor do I obviously think myself, that "uncritical thinking" is a fault of which I have been obviously guilty, especially as my conclusions were all explicitly hypothetical.

The anthropologists who have spent the 48 years from 1931 living with the Dogon tribe are agreed that the knowledge of the Sirius system which they possessed could not have come from Europeans, who in any case had themselves only discovered the superdense nature of Sirius B in about 1926. Knowledge of Sirius B amongst the Dogon goes back hundreds of years, as shown by physical evidence, some of which was even held up in front of television cameras by Dr Germaine Dieterlen, who insisted that it was 400 years old, and said that the European contact theory (espoused by Sagan) was "absurd".

But I do not wish to open this controversy again here. It is in the context of saying that Sagan has shown that the Dogon information "could all have been learnt from contacts with Europeans" (which is untrue) that RowanRobinson does me less than justice by saying this is better than it having "been learnt from little green men in UFOs". I have never at any time suggested this; I went out of my way in my book to say that I do not believe that UFOs are extraterrestrial craft of any kind, or connected with my subject, and RowanRobinson's remarks are therefore a slur against my intelligence and quality of work which I most strongly resent.

Rowan-Robinson also betrays an indefensible bias against the serious possibility that our planet has at some time in its history been visited by intelligent extraterrestrials. What is so remarkable about this per se? Are we so incapable of speculating about these matters that we deny them solely because such a visitation seems to us extraordinary? The electric light bulb would have seemed extraordinary to Plato and Aristotle, but does that rule out the possibility of its eventual invention? This is the kind of inverted logic demonstrated by those whose minds are too small for large notions.

Yours faithfully

ROBERT K.G. TEMPLE

Sutton Mallet, Bridgwater, Somerset, UK

\section{Standardisation of reference citation}

SIR, - A significant part of a scientist's time is spent in drafting manuscripts for publication. Part of this task involves the careful listing and checking of references. At present, most journals have their own distinctive style and even basic references have to be rearranged with considerable waste of time and effort as every new paper is drafted. Some idea of the variability of reference citation can be seen if the bibliographies of the following internationally recognised marine science journals (first published in sequence between 1953 and 1979) are examined: DeepSea Res., Mar. Biol., J. exp. Mar. Biol. Ecol., Estuar. Cst Mar. Sci., Oceanol. Acta., J. Plankton Res. One conclusion that can be drawn from such an examination is that the variability of reference citation is increasing with time.

Some progress has been made towards international standardisation with the introduction of the following international standards: ISO 4-1972 (E), Documentation - International Code for the Abbreviation of Titles of Periodicals and ISO 833-1974, Documentation - International List of Periodical Title Word Abbreviations. (See also BS 4148 Part 1: 1970 and BS 4148 Part 2: 1975.) The establishment of this international standard for over five years does not seem to be acknowledged by many editors (including Nature's) who still recommend the fourth edition of the World List of Scientific Publications for journal abbreviations, a list which was last published in 1963 to 1965 ! In the absence of a properly updated world list and prior to the publication of the new international standard,some journals (such as Journal of the Marine Biological Association of the United

Kingdom) have reverted to printing the full titles of journals.

There is so far no international agreement on bibliographic references, rather the opposite, as the American National Standard ANSI 239.29-1977 and British Standards BS 1629:1976 and BS 5604:1978 differ considerably from each other in their recommendations and from each of the journals cited above. Major differences between the two national standards are the use of capitals, italics and bold face in the British Standard in contrast to a single type face and more complicated punctuation rules in the American standard. The 'Harvard' system with the year of publication following the author and a form of the 'Numeric' system as used in Nature are the two formats recommended in the new British Standards BS 5605:1978 which was specifically prepared for editors and authors of articles in journals and books. The 'Harvard' format comes closest to that now used by most journals. The simpler punctuation of this standard is also preferable, although the adoption of a simple typeface as used in the American system may be more compatible with computerisation of references.

A standard for abbreviated references, as used for instance in Nature, is only given in ANSI 239.29-1977 restricting information to the journal title, volume number, pages and year of publication. This is not sufficient for scientific journals as one needs to assess immediately the 'pedigree' of a particular piece of work by reference to the original authors and if possible an abbreviated title.

Publication of an international standard for bibliographic references in scientific journals is overdue. Major publishing houses, editors of journals and scientists should be consulted in this standardisation process as well as librarians and national standardisation authorities.

Yours faithfully, 